\title{
Development of the Dayak Ngaju Community Forest in the Forest and Peatland Area, Central Kalimantan, Indonesia
}

\author{
Yanarita $^{1)}$, Mohammad Naiem ${ }^{2)}$, Budiadi ${ }^{2)}$, and Sukarna ${ }^{3)}$ \\ ${ }^{I}$ Doctoral Program of Forestry Science . Faculty Of Forestry, University of Gajah Mada, Indonesia \\ ${ }^{2} *$ Faculty of Forestry Science., University of Gajah Mada, Indonesia \\ ${ }^{3}$ Department of Forestry, Faculty of Agriculture, University of Palangkaraya, Indonesia
}

\begin{abstract}
Peat swamp forests are one type of swamp forest that is specific and fragile ecosystems. In order peatland forest ecosystem formed thousands of years, no damage then peatland management should be done wisely by considering the social, economic and cultural as well as ecological functions that peat swamp forest conservation can be guaranteed. This perspective is directly correlated with the paradigm of sustainable forest management. The paradigm explains that the use of natural resources based on the moral ethics that human and nonhuman components are subject to utilization with respect moral and responsible for human rights in addition to the biotic community, and abiotic that still exist and thrive naturally, so it does not compromise the use of " the integrity, stability and beauty" ecosystem.

Dayak Ngaju who resided in forest and peatland in Central Kalimantan have noble values and local wisdom to the development of community forests in forest areas and peatlands. Moral behavior is implemented through the cultural norms carried by generations to support the success of the planting. This study tries to explore the values contained in the Dayak Ngaju cultural norms for development of comunity forests.

Dayak Ngaju community forest development start of cultivation. To ensure the success of planting, Dayak Ngaju very concerned about forest site selection will be opened with a consideration of the physical condition of the land,, which is given by the sign of the animals, and natural phenomena. Each activity in the development of community forests, ranging from land clearing, burning, planting, maintenance and harvesting time very concerned about governance. Dayak Ngaju people do in community forest development activities of mutual cooperation, better known as handep, namely employment with other farmers when working back breaking new ground. Based on the structure and composition of the forest vegetation of the people belonging to the community forest is not purely dominated by rubber sap its main results, and based on the diversity of species diversity in the types being classified with the value 2.4336. Estimated revenue generated from private forest landowners in the region of ex PLG Central Kalimantan in 2010 was Rp.31,898,257.67/ha/year.
\end{abstract}

Key word: dayak ngaju, handep, structure and vegetation composition, and diversity.

\section{Introduction}

Indonesia is a country that has a vast peatlands with approximately 20.697 million ha or $50 \%$ of the peatland area in the world, includes 7.282 million hectares of Sumatra, Borneo 4.413 million ha, 8,91 million ha of Papua, 44.000 ha Sulawesi, and Maluku 48.000 ha (Noor and Suryadiputra, 2004). Disruption of peatland ecosystems such as logging, mining, land conversion, fire, and other causes of forest degradation and peat are very broad. Boehm, et al. (2002) suggested that the rate of degradation of peat swamp forest between the years 1991 to 1997 by $1 . \%$ per year and increased to $6.5 \%$ per year between $1997-2000$, so that the average rate of degradation of peat swamp forest between 1991-2001 of 3.3\%. Between 1997 to 2000 there was an increase in the area of logged forest (logged over area) from 39.566 ha to 59.891 ha of open land and an increase of $54.914,4$ ha in 1991 to $166.130,6$ ha in 2001 .

Destruction of forests and peatlands to the attention of the world, due to its role as a buffer environment. Peat is an absorbing and storing water during the rainy season, but during the dry slowly releasing the stored water. It is important to prevent flooding during the rainy season and water scarcity in the dry season. Besides the role of peat carbon harbored relating to regional and global climate inaugural big enough. Carbon stored in the tropics can reach 5.000 tons/ha, and including 1.200 tons/ha of peat world (Noor,2001). One effort to address deforestation and peatland and its impact, the government sought to build a community forest rehabilitation tailored to the economic and social conditions of the people who do it.

Department of forestry and plantation (2000) explains that the community forest is owned lands that have a crown cover of woody plants more than $50 \%$ with more extensive provisions than $1 / 4$ hectare. Based on the type of plant constituent, community forest is divided into three parts, namely : (1) pristine public forests, community forests which consists of only one type of plant woody trees planted and cultivated in homogeneous or monoculture, (2) a mixture of community forests, community forests which consists of various types of trees are planted in a mixture or polyculture, and (3) agroforestry community forests, community forests that have 
forest establishment combination with other branches of farming, such as plantations, agricultural crops, livestock, etc. integrated manner (Duryat, 1979). It is not much different from the Department of forestry and plantation (2000) which divides the community forests in three groups, namely : (1) community forests based on commodity wood (monoculture), (2) community forest that have mixed commodities (wood and non-wood), and (3) community forest that have recreation services comodities. While based way, community forests are formed in 2 ways (Suhardjito, et al., 2000), namely : (1) through the intervention of planting activities generally starts from cultivation (rice cultivation), and when the factors of soil fertility constraints to rice cultivation further planting crops (annual crops), and (2) derived from changes in the shape and function of natural forests to managed forests, cultivated and utilized by individuals or a group of people in the countryside. Thus a garden (talun gardens) are only covered by a few trees can be categorized as community forests.

Peat swamp forests are one type of swamp forest that is specific and fragile ecosystems. Therefore, the management of peatlands should be done wisely by considering the social, economic and cultural as well as ecological functions that peat swamp forest conservation can be guaranteed. Public policy in the utilization of peat contained in the Presidential Decree number 32/1990 that the peat soil to a depth of $3 \mathrm{~m}$ or more protected areas categorized as an area that should not be disturbed or a conservation area.

Dayak tribe is divided into 6 large clumps, namely : Kenyah-Kayan-Bahau, Ot-Danum, Iban, Murut, Klemantan, and Punan. These clumps to six subdivided into approximately 405 sub-tribes. Although divided into hundreds of sub-tribe, the Dayak tribe have the same distinctive characteristics, such as: the long house, the cultivation system, livelihood, material culture results (saber, chopsticks, pottery, beliong) and dance (Riwut,1958; Ukur, 1994). And the Dayak people residing the forests and peatland region of ex PLG in Central Kalimantan including clump Ot-Danum sub Dayak Ngaju (Dayak Kahayan). Dayak community needs to obtain dry rice cultivation system that gave birth to understand natural phenomena that affect the cultivation especially when opening forest. Sistem farming land which changed the face of the forest in accordance with the cultural patterns that will give birth to a rubber plantation to secondary forests become a livelihood for people Dayak before used again for agriculture is a concept siffting cultivation or swidden (Ave and King in Arman, 1994).

The concept of shifting childbirth rubber plantations resembling secondary forest which in this study is referred to as community forests. The Dayak Ngaju proved able to balance environmental protection functions and functions economic needs. When compared with the forest management carried out by the concession or plantation (in force since forest management outside Java 1970s) causing tremendous damage to forests. Dayak Ngaju indigenous communities in forest management and land is a wealth of noble values which can be one of the examples or models to improve forest management and environmental systems currently damaged. Noble values embodied in the concept of farming that produces Dayak Ngaju community forests in forest and peatlands areas.

The strategic role of the noble values of the Dayak Ngaju in managing community forests in forest and peatland directly support the paradigm of forest sustainable management. The adoption paradigm of sustainable forest management as sustainable development paradigm that is expressed Simon (2004). The paradigm explains that the use of natural resources based on the moral ethics that human and nonhuman components are subject to utilization with respect moral and responsible for human rights in addition to the biotic community, and abiotic that still exist and thrive naturally, so it does not compromise the use of "the integrity, stability and beauty" ecosystem.

Associated with the strategic role of the noble values of the Dayak Ngaju in managing community forests in forest areas and peatlands, this study will empirically explain a few things, among others : (1) The pattern of community forest management done in the area of the Dayak Ngaju ex PLG Central Kalimantan, (2) the structure and composition of vegetation that form of community forests, and (3) income derived from the activities of community forests as a function of economic needs of society.

\section{Research Methods}

This study includes descriptive study. The study object is selected community forests with porpusive sampling criteria: (1) land that has belonged to crown cover of woody plants more than $50 \%$ with more extensive provisions than $1 / 4$ hectare $(\mathrm{MoF}, 2001)$, (2) the pattern of cropping is relatively the same, (3) intensively managed by the owner, and (4) has given the crop yields or benefits of woody plants and its associated commodity or at least a minimum of 7 years standing woody.

These results reflect the entire population of the former area of public forests in Central Kalimantan PLG region that has the characteristics and patterns of community forest management is relatively the same. The number of community forests that serve absolutely no research object representation based on population, but rather based on how much forest is able to provide an overview of the people selected to achieve the expected goals of study (Marjuki, 2005). A large number of community forests that made the object of research is 15 units of land. 
Kodir (2009) and Paembonan (2008) explains that the calculation approach IVI and H' in the garden and agroforestry refers to a method of inventory and measurement of natural forest vegetation by calculating IVI protocol and H' (Dombois and Ellenberg, 1974). Location of the plot for the calculation of IVI and H' pursued spread evenly in each community forest unit with the distance of each plot ranged between 10-30 m. More precisely determining the location of the plot for the calculation of IVI and H' as shown below.

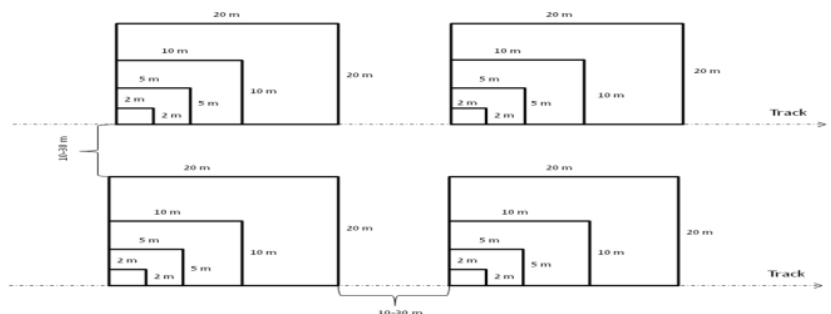

Fig 1 . Determination of Vegetation Inventory Plot Layout for Calculation of Important Values Index (IVI) and Diversity Vegetation Types (H') of Community Forest.

Conditions : (1) plot size of $20 \mathrm{x} 20 \mathrm{~m}$ to count and measure the circumference/diameter of the treelevel vegetation, namely: woody plants with a diameter limit of $>20 \mathrm{~cm}$ (diameter measurements taken at a height of $1.3 \mathrm{~m}$ from ground level), (2) plot size of $10 \times 10 \mathrm{~m}$ for counting and measuring vegetation poles, namely: woody plants with a diameter limit of $10-20 \mathrm{~cm}$, (3) a plot size of $5 \mathrm{x} 5 \mathrm{~m}$ to calculate and measure the vegetation of saplings, namely: high woody plants that have $>1,5 \mathrm{~m}$ with a diameter of 5-9 cm, (4) $2 \times 2 \mathrm{~m}$ plot to calculate and measure vegetation seedlings, namely : vegetation with a number of more than 2 pieces of leaves and height between $30-150 \mathrm{~cm}$.

Data processing for the IVI calculation, obtained of the sum of relative density, relative frequency, and relative dominance with the formula Dombois and Ellenberg, 1974:
a. density (trunk/ha)
$=$ number of individuals of a species
b. the relative density $(\%)$
widespread throughout the plot
c. frequency
$=$ density of a species x $100 \%$
= number of plots containing a type
d. relative frequency $(\%)$
e. species dominance $\left(\mathrm{m}^{2} / \mathrm{ha}\right)$
the total number of plots
$=$ frequency of a species
the total number of plots
$=$ the area of a kind
f. relative dominance $(\%)$
widespread throughout the plot
$=$ dominance of a species $\mathrm{x} 100 \%$ dominance all types

Diversity is a greater diversity of vegetation in a forest area which is calculated as the Shannon index (Ludwig and Reynolds, 1988) as follows:

where :

$$
\mathrm{H}^{\prime}=\sum_{i=n}^{n} p i \cdot \ln \cdot p i
$$

$$
\begin{aligned}
& p i=\mathrm{ni} / \mathrm{N} ; \\
& \mathrm{ni}=\mathrm{IVI} \text { of a kind; } \\
& \mathrm{N}=\text { IVI all types; } \\
& \ln =\text { natural } \log (\mathrm{e}=\text { natural numbers }=2.714) .
\end{aligned}
$$

Criteria value $\mathrm{H}^{\prime}$ :

If the value of $\mathrm{H}^{\prime}<2$ means low species diversity,

If the value of $\mathrm{H}^{\prime}=2-4$ means the diversity of being,

If the value of $\mathrm{H}^{\prime}>4$ means high species diversity.

For income derived from public forests is done by summing the production obtained from the community forest activities multiplied by the price of each production at the time the study was conducted using the general formula (Simon, 2010) as follows : $\mathrm{Yr}=\sum_{i=1}^{i}(H i x p i)_{3}$

where : 
$\mathrm{Yr}=$ income ;

$\mathrm{Hi}=$ the price of commodities, and

$\mathrm{Pi}=$ the " $\mathrm{i}$ " output.

The study was conducted in the village of Jabiren, Pulang Pisau district of Central Kalimantan, Indonesia. Location research is an area of one million hectares of ex PLG who have discontinued their implementation in 1998 for causing tremendous environmental damage to ecosystems and socio-economic surroundings. Locations complete study can be seen in the map below.

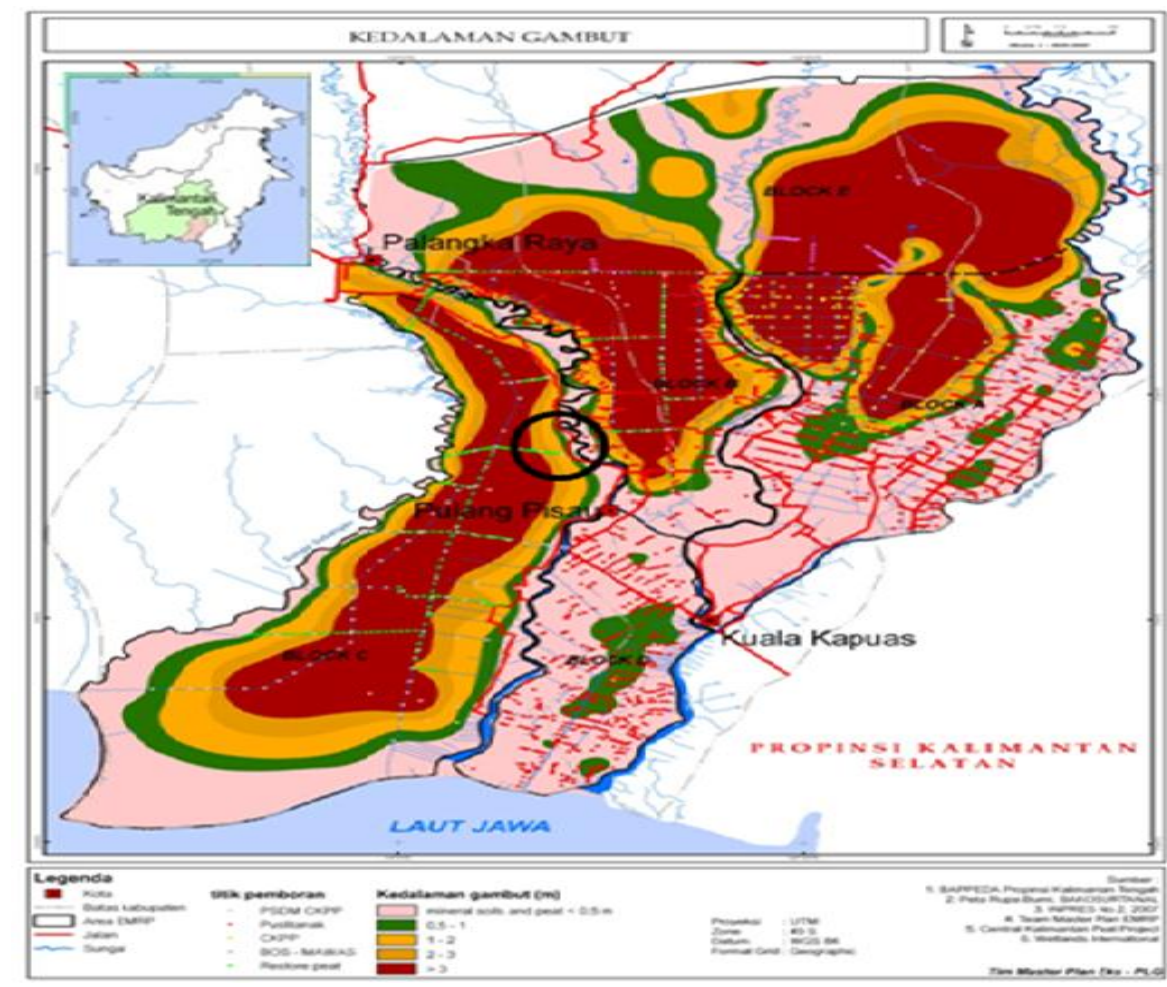

Fig 2: Research Location Map of Community Forest in ex PLG Region Central Kalimantan

\section{Empirical Results}

This study methodology has the objective of which, are: (1) determine the pattern of land management in the development of community forests, (2) determine the structure and composition of the constituent vegetation community forests, and (3) determine the income derived from the activities of community forests. The results of the study explained in full as follows:

\section{Pattern of Land Management}

The pattern of land management of community forest of the Dayak Ngaju in ex PLG Region Central Kalimantan described in the table below.

Table 1. Patterns and Procedures of Processing Time of Community Forest of the Dayak Ngaju

\begin{tabular}{lll}
\hline No. & Descriptions & Planning Time \\
\hline 1. & Land opening: & $\mathrm{t}^{-1-2 \text { month }}$ \\
& a. Making firebreaks (moat) surrounding land & $\mathrm{t}^{-1 \text { month }}$ \\
& b. Slash, burn, dan land clearing & $\mathrm{t}$ \\
2. & Planting: & $\mathrm{t}$ \\
& a. Rice plants & $\mathrm{t}^{+2-4 \text { month }}$ \\
& b. Perennials & $\mathrm{t}^{+5-6 \text { month }}$ \\
3. & Maintenance: grazing & $\mathrm{t}^{+1-3 \text { year }}$ \\
5. & Harvesting rice plants & $\mathrm{t}^{+7-25 y e a r}$ \\
\hline
\end{tabular}

Description $: \mathrm{t}=$ time of planting, $\mathrm{t}=$ time before planting, $\mathrm{t}+=$ time after planting 
Pattern and order processing time by the community forest of the Dayak Ngaju in ex PLG region can be described as follows.

\section{a. Land Opening}

Forest clearance was first performed in the dry season, usually around the month of June-July is by logging on small trees generally below $30 \mathrm{~cm}$ in diameter and slashing bushes. Trees or shrubs that have been cut down the middle were collected to land, and during the dry season in order to dry quickly and easily burned.

How to field burning is practiced Dayak Ngaju tribes in Central Kalimantan also contain elements of the prevention of fire spread, namely : (1) combustion is generally done when the scorching hot midday peak and the wind is not blowing hard, (2) burning activities carried out contrary to the direction of the wind, meaning that the fire does not spread quickly that the burning material becomes longer and produce better burnt ash, and (3) the activities carried burning just one day, or when the location of abandoned land is not left burning flames to avoid fire when the site was abandoned. Elements of precaution against fire hazard this gives an indication that the widespread burning by way of Dayak Ngaju can be a limiting factor for the wide open field. Areas of forest or peatland opened fields ranging from 1-2 ha.

Peatlands have a high content of organic matter with thicknesses ranging from less than 0,5 meters to a depth of more than $20 \mathrm{~m}$. Type of soil classified organosol, podsol and glei humus (Daryono, 2009). Peat soils have low fertility with a high degree of acidity. According Subagyo (1997) shallow peat has a pH between 4,0 to 5,1 , whereas in the peat has a $\mathrm{pH}$ between 3,1 to 3,9. Burning land will decompose organic matter content is high, increasing the $\mathrm{pH}$ of the soil so that a high degree of soil acidity can be neutralized so that the plants can grow well.

\section{b. Planting}

Planting activities carried out when the rainy season, usually around October-November. As part of the activities of farming, planting of woody plants or woody vegetation as a forerunner of community forests is done before or in conjunction with plant rice (manugal). For the Dayak community, manugal activities generally absorb labor outside the family members. Outside employment of family members carried handep called mutual aid. Handep is a reciprocal term work outside the family in the Dayak community cultural activities such as farming, marriage, death, and others.

Planting perennials/woody vegetation is done before or in conjunction with activities manugal, because: (1) the efficiency of labor, (2) maintenance of woody vegetation for seedlings can be more intensive because it coincides with the rice plant maintenance activities, thus guarantees higher living woody vegetation, (3) the planting of woody vegetation does not interfere or step on rice seedlings that have been planted. Woody vegetation along with the cultivation of rice planting woody vegetation often cause irregular cropping distance. If further investigation, the pattern of woody vegetation in the farming activity is first eligible sustainable forest management concept that was born in Germany, which is a guarantee of success in the field planting (Simon, 2010). The basic pattern of community forest vegetation of Dayak Ngaju can be seen in the figure below.

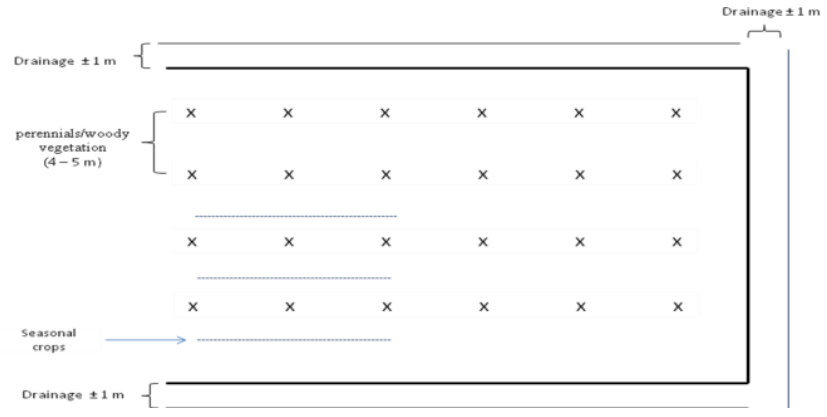

Fig 3 . Basic Pattern Perennials Planting in the Community Forest

\section{c. Maintenance Perennials}

Maintenance of woody plants as the forerunner of community forests do for 1-6 years, by slashing shrubs or bushes that interfere with plant growth. Shrubs are generally grown in the community forest peat being is: ferns (Stenochlaena palustris), reed (Imperata cylindrica), Karamunting (Melastoma malabatricum), and nut-grass (Cyperus rotundus). Cleaning shrubs ferns are particularly difficult job for farmers because this shrub has a strong rooting and spreading.

\section{d. Harvesting}


Forest harvesting activities of the people in the Dayak Ngaju is tapping rubber, and or harvesting fruit on fruiting season. Rubber tapping activities in the Dayak Ngaju is large enough to absorb labor. Because besides intercepted by landowners, tapping activities also can be done by workers from outside the family. Earned income is the owner and tapper system for the results. In the study site, the sharing system for owners and tapper is 2:3, which means when the rubber is obtained as much as $50 \mathrm{~kg}$, then the result is $20 \mathrm{~kg}$ to $30 \mathrm{~kg}$ and the land owner to eavesdroppers.

\section{Structure and Composition Vegetation of the Community Forest}

The results of the vegetation analysis to determine the structure and composition of vegetation stands by calculating IVI the community forest is being presented in Table 2.

Table 2 . Important Value Index Vegetation of Community Forests

\begin{tabular}{|c|c|c|c|c|c|c|}
\hline \multirow{2}{*}{ No } & \multirow{2}{*}{ Local Name } & \multirow{2}{*}{ Latin Name } & \multicolumn{4}{|c|}{ IVI } \\
\hline & & & Seeding & Sapling & Pole & Tree \\
\hline 1 & Sungkai & Peronema canescens Jack. & - & - & 30,2096 & - \\
\hline 2 & Acacia & Acacia mangium & - & - & 1,8369 & - \\
\hline 3 & Teak & Tecona grandis & - & - & 16,2037 & - \\
\hline 4 & Sengon & Paraseriantes falcataria & - & - & 7,3476 & - \\
\hline 5 & Gelam & Mellaleuca leucadendron & - & - & 3,6738 & - \\
\hline 6 & Kalapapa & - & - & - & 1,8369 & - \\
\hline 7 & Kaja & - & - & - & 4,0347 & - \\
\hline 8 & Meranti & Shorea belangeran & - & - & 4,7889 & - \\
\hline 9 & Rubber & Hevea brasiliensis & - & - & 114,1478 & - \\
\hline 10 & Jelutung & Dyera costulata & - & - & 50,8090 & - \\
\hline 11 & Jackfruit & Arthocarpus heterophyllus Lamk. & - & - & 4,7727 & - \\
\hline 12 & Cempedak & Arthocarpus champeden & - & - & 22,0753 & - \\
\hline 13 & Paken & Durio kutejensis & - & - & 5,1498 & - \\
\hline 14 & Coconut & Cocos nucifera $\mathrm{L}$. & - & - & 1,8369 & - \\
\hline 15 & Rambutan & Nephelium lappaceum & - & - & 20,2547 & - \\
\hline 16 & Jengkol & Archidendron pauciflorum & - & - & 1,8369 & - \\
\hline 17 & Areca Nut & Areca cathecu & - & - & 1,8369 & - \\
\hline 18 & Mango & Mangifera indica $\mathrm{L}$. & - & - & 7,3476 & - \\
\hline 19 & Citrus fruit & Citrus aurantifolia & - & 28,5714 & - & - \\
\hline 20 & Bark & Salacca zalacca (Gaertn.) Voss & - & 28,5714 & - & - \\
\hline 21 & Rattan & Calamus, sp & - & 57,1429 & - & - \\
\hline 22 & Bananas & Musa acuminate & - & 28,5714 & - & - \\
\hline 23 & Oil Palm & Elaeis guineensis & - & 57,1429 & - & - \\
\hline 24 & Eggplant & Solanum melongena $\mathrm{L}$. & 58,3333 & - & - & - \\
\hline 25 & Ferns & Stenochlaena palustris & 100,0000 & - & - & - \\
\hline \multirow[t]{2}{*}{26} & Cassava & Manihot utilissima Pohl & 41,6667 & - & - & - \\
\hline & & & 200,00 & 200,00 & 300,00 & \\
\hline
\end{tabular}

Table 2 illustrates that the IVI community forest consists of three levels, namely: seedlings, stakes and poles. IVI vegetation tree level can not be found because the community forest research sample age range 7-12 years its standing still. Constituent community forest vegetation types dominated by exotic vegetation or not a natural peat forest vegetation such as : Hevea brasiliensis, Acacia mangium, Paraseriantes falcataria, and only found 4 types of vegetation which is the natural vegetation of peat, namely : Peronema canescens Jack., Mellaleuca leucadendron, Shorea belangeran, Dyera costulata and within a few percent.

Table 2 also provides information that the first choice of plant species for the Dayak Ngaju community in planting on private land is Hevea brasiliensis. For the Dayak Ngaju community, Hevea brasiliensis is a sap producing annual crops, the cultivation rotation to regain soil fertility. Dayak Ngaju community forest in determining the choice of plant species is highly dependent on the real benefits that have been perceived (economic benefits now) and through the most efficient way (the availability of seeds). 
The second annual plant selection to plant on community land is Dyera costulata. Dyera costulata is the type of vegetation that grows in the forest peat and primary production sap (for chewing gum). Dyera costulata have straight trunks and high, Bulk Density has a 0,40 grade durable with strong class V and III-V, can be used for carpentry, but not appreciated by the public. The destruction of peat forests in the ex PLG region led to the existence of Dyera costulata reduced. Dyera costulata including peat forest vegetation types are easy to breed with seeds.

The third annual plant selection is Peronema canescens Jack. Peronema canescens Jack is generally growing vegetation in the river sidelines especially in the depth of the peat being. Peronema canescens Jack planting on private land is a pilot program of community forest development in 2003. From the interview, test program development of community forests in monoculture is no positive impact for the development of community forests. Society has not been motivated to develop a broader Peronema canescens Jack. It can be seen from the absence of Peronema canescens Jack on land owned by the government but developed from pilot activities development of community forests.

The selection of plant species to forest people pay attention to the following requirements (Department of Forestry, 1995) : (1) the suitability of land and climate, (2) the desire of the people, (3) high and versatile benefits for the community, (4) has economic value and easy marketed, (5) fast growing and rapidly produce; (6) types that serve to protect and nourish the soil, and (7) have the benefit of the water system protection and environmental preservation. While Simon (2004) suggested that the selection of tree species used for the development of community forests should be chosen in order to meet several criteria: (1) in accordance with the climatic conditions, soil type and soil fertility and physical properties of the region (environmentally friendly), (2) rapid produce and can be easily cultivated by society (socially acceptable), and (3) produce a marketable commodity and raw materials meet the industry (economically profitable). Selection of community forest vegetation types such as : Hevea brasiliensis, Dyera costulata and Peronema canescens Jack actually meet the criteria for two. However, when associated with a type of wood that is appreciated by the public as a building material or for the fulfillment of industrial wood from natural forests surrounding peat, namely: Shorea belangeran, Palaquium rostratum, Gonystylus bancanus, Dryobalanops sp, then the choice of the people of the forest vegetation is not meet people's needs and requirements timber industry.

The results of the calculation of species diversity $\left(\mathrm{H}^{\prime}\right)$ seedlings to forest vegetation is 0,3779 , for the stake level is 0,6093 , and 1,4464 for the pole. Overall diversity of the people of the forest vegetation in peat being is 2,4336 . Thus it can be said that the level of species diversity of forest vegetation tends polyculture or $\mathrm{H}^{\prime}=2-4$. According to Simon (2010) polyculture forest is very helpful in reducing carbon dioxide in the air. The existence of carbon dioxide is closely related to global warming. With the high binding ability of carbon dioxide from the air, polyculture community forests have bigger role in reducing the rate of global warming. But it must be remembered, peat has a specific nature in its function as a carbon dioxide absorber. Carbon stored below ground surface (peat layer) can be 10 times greater than the carbon stored above the surface (Notohadiprawiro, 1998). Carbon stored in peat soils ranged $18-60 \%$ weight equivalent to 0,03 to $0,07 \mathrm{tm}^{-3}$, while the mineral soil only around $0,5-5 \%$ weight equivalent to 0,005 to $0,050 \mathrm{tm}^{-3}$ (Agus, 2007).

\section{Revenue}

Estimated revenue generated from private forest landowners in 2010 can be seen in the table below.

Table 3: Revenue earned landowners of the Community Forest

\begin{tabular}{|c|c|c|c|c|}
\hline No & Latin Name & $\begin{array}{l}\text { The main } \\
\text { usefulness }\end{array}$ & Unit & $\begin{array}{l}\text { Revenue } \\
\text { (IDR/Ha/year) }\end{array}$ \\
\hline & Annual Crops & & & \\
\hline 1 & Hevea brasiliensis & Sap & $\mathrm{kg} / \mathrm{month}$ & $18.951 .342,28$ \\
\hline 2 & Dyera costulata & Sap & $\mathrm{kg} / \mathrm{month}$ & $2.610 .826,56$ \\
\hline 3 & Arthocarpus heterophyllus Lamk. & Fruit & seed & $79.477,22$ \\
\hline 4 & Arthocarpus champeden & Fruit & seed & $2.461 .586,01$ \\
\hline 5 & Durio kutejensis & Fruit & seed & $5.004 .121,04$ \\
\hline 6 & Cocos nucifera $\mathrm{L}$ & Fruit & seed & $1.766,16$ \\
\hline 7 & Nephelium lappaceum & Fruit & unit & $2.575 .650,54$ \\
\hline 8 & Citrus aurantifolia & Fruit & seed & $2.649,24$ \\
\hline 9 & Areca cathecu & Fruit & $\mathrm{kg}$ & $2.943,60$ \\
\hline 10 & Mangifera indica $\mathrm{L}$. & Fruit & seed & $82.420,82$ \\
\hline 11 & Salacca zalacca (Gaertn.) Voss & Fruit & $\mathrm{kg}$ & $4.415,40$ \\
\hline \multirow[t]{3}{*}{12} & Calamus, $s p$ & Rattan & bar & $75.061,82$ \\
\hline & Total I & & & $31.852 .484,69$ \\
\hline & Seasonal Crops & & & \\
\hline 1 & Musa acuminate & Fruit & unit & $8.830,80$ \\
\hline 2 & Solanum melongena $\mathrm{L}$. & Vegetable & $\mathrm{kg}$ & $19.075,00$ \\
\hline 3 & Stenochlaena palustris & Vegetable & unit & $2.207,70$ \\
\hline 4 & Elaeis guineensis & Vegetable & tree & $2.943,60$ \\
\hline
\end{tabular}




\begin{tabular}{|c|c|c|c|c|}
\hline 5 & Manihot utilissima Pohl & Vegetable & $\mathrm{kg}$ & $12.716,35$ \\
\hline & Total II & & & $45.772,99$ \\
\hline & Total I + II & & & 31.898.257,67 \\
\hline
\end{tabular}

In Table 3. can be know that the largest land owners of income derived from the sap of rubber or jelutung. However, the amount of income earned from harvesting the sap of rubber or jelutung, not wholly owned by the owner of the land. This is due to the harvesting activity, income earned by the land owners can be divided labor eavesdroppers outside family members. Meanwhile, the income derived from fruits or vegetables is earned income when expressed in terms of money.

\section{Conclusion}

This study describes the values of indigenous Dayak communities in managing forest lands and peatlands in establishing community forests. In addition to the above factors that need to be done in establishing community forests, among which:

1. Development of community forests in peat not only pay attention to the depth of the peat just as stated in the Presidential Decree Number.32/1990 that the peat depth of $3 \mathrm{~m}$ or more for protected areas, but at a depth of less than $3 \mathrm{~m}$ can be not suitable for the development of community forests. Required the selection of the right location to get a guarantee planting success, given the peat is a fragile region that ultimately affect its role in the wider environment.

2. Structure and composition of the community forest vegetation types were identified, totaling 26 types consist of 3 levels (seedling, sapling, and pole), with species selection based on economic needs and the availability of seed for a living (income) for the owner.

3. Increased productivity of the vegetation community forest timber requires intervention especially timberplanting vegetation natural peat forest vegetation.

\section{References}

[1]. Agus, F. 2007. Cadangan, Emisi, dan Konservasi Karbon pada Lahan Gambut. Potpourri Flowers Papers on Soil and Water Conservation. Pengurus Pusat Masyarakat Konservasi Tanah dan Air Indonesia 2004-2007. Jakarta.

[2]. Arman, Syamsuni. 1994. Analisa Budaya Dayak, In Paulus Florus (Ed), Kebudayaan Dayak: Aktualisasi Dan Transformasi, Jakarta: Grashindo Utama.

[3]. Boehm, H.D.V., Siegert, F. and Liews, S.C. Remote Sensing and Aerial Survey of Vegetation Cover Change in Lowland Peat Swamp Forest of Central Kalimantan during the 1997 and 2002 Fires. Proceeding of The International Symposium on Land Management and Biodiversity in Southeast Asia. Research center for Biology. The Indonesia Institute of Sciences, Bogor. Indonesia.

[4]. Campbel BM. 2004. Empowering Forest Dwellers and Managing Forests More Sustainability in the Landscapes of Borneo. www.cifor.cigar.org.case4.pdf

[5]. Daryono, H., 2009. Potensi, Permasalahan dan Kebijakan yang Diperlukan Dalam Pengelolaan Hutan dan Lahan Gambut Secara Lestari. Journal of Forestry Policy Analysis Vol. 6 No. 2, Agustus 2009 : $71-101$

[6]. Department of Forestry and Plantation, 2000, Undang-undang No. 41, Tahun 1999 about Kehutanan, Departemen Kehutanan dan Perkebunan, Jakarta.

[7]. Department of Forestry, 1995. Hutan Rakyat. Departemen Kehutanan RI. Jakarta.

[8]. Dombois. M. and Ellenberg. H., 1974. Aims dan Methods of vegetation Ekology. Wiley International Edition. John Wiley and Sons. New York.

[9]. Dove, M., 1988. Sistem Perladangan Di Indonesia: Studi kasus Di Kalimantan Barat, Yogyakarta: Gajahmada University Press.

[10]. Ukur, F.,1994. Makna Religi dari Alam Sekitar Dalam Kebudayaan Dayak, Dalam Paulus Florus (Ed), Kebudayaan Dayak: Aktualisasi Dan Transformasi, Jakarta: Grashindo Utama.

[11]. Kodir, A. 2009. Keanekaragaman dan Bioprospek Jenis Tanaman dalam Sistem Kebun Talun di Kasepuhan Ciptagelar Desa Sirnaresmi Kecamatan Cisolok Sukabumi Jawa Barat. Disertasi. IPB. Bogor.

[12]. Ludwig, J.A., dan Reynolds, J.F., 1988. Statistical Ecology, A Primer on Method and Computing. John Wiley and Sons. New York.

[13]. Marjuki, 2005. Metode Riset. Panduan Penelitian Bidang Bisnis dan Sosial. Penerbit Ekosia Kampus Fakultas Ekonomi. UII Yogyakarta.

[14]. Mc. Kinsey, 2009. Mengembangkan Strategi Pertumbuhan Ekonomi Rendah Karbon untuk Kalimantan Tengah. Presented in Workshop Mengembangkan Strategi Pertumbuhan Ekonomi Rendah Karbon untuk Kalimantan Tengah. Palangka Raya. 5 November 2009.

[15]. Noor, M., 2001. Pertanian Lahan Gambut. Potensi dan Kendala. Penerbit Kanisius. Yogyakarta.

[16]. Noor, Y.R. dan I Nyoman N. Suryadiputra, 2004. Pengelolaan Lahan Gambut di Indonesia. Potensi dan Tantangan. Prosiding Sustainable Peatland Management Workshop. Date 30 Nopember 2004. Jakarta.

[17]. Paembonan, S.A. 2008. Model Agroforestry Berbasis Tongkonan yang Berwawasan Konservasi Lingkungan di Kabupaten Tana Toraja. Universitas Hasanuddin. http://repository.unhas.ac.id/handle/123456789/4388.

[18]. Riwut, Tj. 1958. Kalimantan Memanggil, Jakarta: Penerbit Endang.

[19]. Simon, H., 2004, Membangun Kembali Hutan di Indonesia, Pustaka Pelajar, Yogyakarta.

[20]. ............,2010. Dinamika Hutan Rakyat di Indonesia. Pustaka Pelajar. Yogyakarta.

[21]. Suharjito, D., Khan, A., Djatmiko, W.A., Sirait, M.T., dan Evelyna, S. 2000. Pengelolaan Hutan Berbasiskan Masyarakat. Pustaka kehutanan Masyarakat. Aditya Media. Yogyakarta. 